\title{
Comprehensive genetic analyses of primary adrenal failure without enzymatic defects
}

\author{
Naoko Amano ${ }^{1 *}$, Mie Hayashi ${ }^{2}$, Satoshi Narumi ${ }^{1}$, Koji Muroya ${ }^{3}$, Rika Kizu ${ }^{4}$, Hiroshi Mochizuki ${ }^{5}, Y_{\text {Mko Taniguchi }}{ }^{6}$, \\ Hiroki Matsuura7, Keiko Homma ${ }^{8}$, Tomonobu Hasegawa ${ }^{1}$ \\ From 7th APPES Biennial Scientific Meeting \\ Nusa Dua, Bali. 14-17 November 2012
}

Our objective is to estimate frequencies of mutations in STAR, CYP11A1, NROB1, NR5A1, MC2R, and MRAP in a cohort of Japanese patients with primary adrenal failure without enzymatic defects. Twenty-one patients were included, who were diagnosed as having primary adrenal failure without enzymatic defect, namely 21-hydroxylase deficiency, $3 \beta \mathrm{HSD}$ deficiency, $11 \beta$-hydroxylase deficiency, and $\mathrm{P} 450$ oxidoreductase deficiency. Sixteen patients presented with primary adrenal failure before the age of 2 years. Fourteen patients had apparent mineralocorticoid deficiency. Fourteen patients were 46, XY and 7 patients 46, XX. Three had 46, XY disorders of sex development. Mutation analyses of STAR, NROB1, NR5A1, MC2R, and $M R A P$ were done by PCR-based sequencing and next generation sequencing. In case of no amplification of NROB1 by PCR, we performed oligonucleotide array CGH. We descried clinical findings in each patients and determined possible genotype-phenotype correlation. Five patients were diagnosed as having DAX-1 deficiency. NROB1 mutations were found hemizygously in 3 patients (c.116delG, c.846_865del, and p.Q283X). NROB1 deletions were found in 2 patients $(400 \mathrm{~kb}$ deletion including NROB1 and $2.4 \mathrm{~kb}$ deletion of exon 1 ). Four patients presented with primary adrenal failure in newborn, and the other patient presented at the age of 6 years. STAR mutations were found in 3 patients. One patient was $46, \mathrm{XY}$, and 2 patients were $46, \mathrm{XX}$. One patient, who presented with primary adrenal failure in newborn, had c.712delA/p. Q258X. Two patients, who presented at preschool age, had p.Q258X/p.R272C and p.Q258X/p.R188H. No mutations were found in CYP11A1, NR5A1, MC2R, and MRAP. In conclusion, $N R O B 1$ mutations and deletions are relatively common in 46 , $\mathrm{XY}$ normal male phenotype

${ }^{1}$ Keio University School of Medicine, Tokyo, Japan patients (5/11). STAR mutations might be found in cases, being older than 2 years of age. 3. CYP11A1, NR5A1, $M C 2 R$, and $M R A P$ mutations are rare.

\section{Authors' details}

${ }^{1}$ Keio University School of Medicine, Tokyo, Japan. ${ }^{2}$ Ohtsuka Metropolitan Hospital, Tokyo, Japan. ${ }^{3}$ Kanagawa Children's Medical Center, Kanagawa, Japan. ${ }^{4}$ Yokosuka Kyosai Hospital, Kanagawa, Japan. ${ }^{5}$ Saitama Children's Medical Center, Saitama, Japan. ${ }^{6}$ International University of Health and Welfare Hospital, Tochigi, Japan. ${ }^{7}$ Shinshu University School of Medicine, Nagano, Japan. ${ }^{8}$ Keio University Hospital, Tokyo, Japan.

Published: 3 October 2013

doi:10.1186/1687-9856-2013-S1-P109

Cite this article as: Amano et al:: Comprehensive genetic analyses of primary adrenal failure without enzymatic defects. International Journal of Pediatric Endocrinology 2013 2013(Suppl 1):P109.

Submit your next manuscript to BioMed Central and take full advantage of:

- Convenient online submission

- Thorough peer review

- No space constraints or color figure charges

- Immediate publication on acceptance

- Inclusion in PubMed, CAS, Scopus and Google Scholar

- Research which is freely available for redistribution

Submit your manuscript at www.biomedcentral.com/submit
() Biomed Central
Full list of author information is available at the end of the article

C Biomed Central

C 2013 Amano et al; licensee BioMed Central Ltd. This is an Open Access article distributed under the terms of the Creative Commons Attribution License (http://creativecommons.org/licenses/by/2.0), which permits unrestricted use, distribution, and reproduction in any medium, provided the original work is properly cited. 